\title{
PENGARUH PENGAWASAN, SISTEM AKUNTANSI DAN PENGELOLAAN KEUANGAN DAERAH TERHADAP KINERJA PEMERINTAH DAERAH
}

\author{
Sitti Murniati \\ Program Studi Akuntansi STIE Wira Bhakti Makassar \\ STIE Wira Bhakti \\ e-mail: sittimurniati@ymail.com
}

\begin{abstract}
Abstrak
Kinerja Pemerintah Daerah mencakup pengkuran kinerja keuangan dan non-keuangan. Dalam mengukur kinerja, diperlukan indikator kinerja. Indikator kinerja Pemerintah Daerah memiliki karakteristik yang relatif lebih rumit jika dibandingkan dengan indikator kinerja organisasi privat karena indikator kinerja Pemerintah Daerah lebih didominasi oleh indikator kinerja non-keuangan dibandingkan indikator keuangan. Pengukuran kinerja Pemerintah Daerah merupakan proses mencatat, mengukur pencapaian pelaksanaan kegiatan dan anggaran dalam arah pencapaian misi melalui hasil-hasil yang ditampilkan berupa produk, jasa ataupun suatu proses pelayanan publik. Tujuan penelitian adalah untuk menganalisis pengaruh pengawasan, sistem akuntansi dan pengelolaan keuangan daerah terhadap kinerja Pemerintah Daerah, baik secara parsial maupun secara simultan. Sampel penelitian bersumber dari 60 orang pegawai Pemerintah Daerah dan metode analisis yang digunakan adalah analisis regresi berganda dengan program IBM SPSS Statistics. Hasil penelitian menunjukkan bahwa pengawasan, sistem akuntansi dan pengelolaan keuangan daerah berpengaruh positif dan signifikan terhadap kinerja Pemerintah Daerah, baik secara parsial maupun secara simultan dan pengawasan adalah variabel yang paling dominan berpengaruh terhadap kinerja Pemerintah Daerah.
\end{abstract}

Kata kunci: Pengawasan, Sistem Akuntansi, Pengelolaan Keuangan Daerah dan Kinerja Pemerintah Daerah

\begin{abstract}
Local Government performance includes financial and non-financial performance measurements. In measuring performance, performance indicators are needed. Local Government performance indicators have relatively more complicated characteristics when compared to private organization performance indicators because Local Government performance indicators are more dominated by nonfinancial performance indicators than financial indicators. Measurement of Local Government performance is the process of recording, measuring the achievement of activities and budget implementation in the direction of achieving the mission through the results displayed in the form of products, services or a public service process. The research objective was to analyze the effect of supervision, accounting systems and regional financial management on local government performance, either partially or simultaneously. The research sample came from 60 local government employees and the method of analysis used was multiple regression analysis with the IBM SPSS Statistics program. The results showed that supervision, accounting systems and regional financial management had a positive and significant effect on local government performance, either partially or simultaneously and supervision was the most dominant variable affecting local government performance.
\end{abstract}

Keywords: Supervision, Accounting System, Regional Financial Management and Local Government Performance

\section{PENDAHULUAN}

Pemerintah Daerah sebagai organisasi nirlaba merupakan organisasi sektor publik milik Pemerintah dan menempatkan organisasi ini mempunyai keunikan yang sangat berbeda dengan organisasi bisnis. Pemerintah Daerah mempunyai tanggungjawab besar 
dibidang ekonomi dan sosial secara bersama yaitu pengukuran kinerja Pemerintah Daerah harus mempertimbangkan indikator-indikator ekonomi dan sosial secara komprehensif. Keberhasilan otonomi daerah tidak lepas dari pengukuran kinerja Pemerintah Daerah. Pengukuran kinerja Pemerintah Daerah merupakan suatu evaluasi terhadap organisasi Pemerintah Daerah tentang kegiatan yang telah dilaksanakan berdasarkan tolok ukur yang telah dibuat sesuai standar minimum pelayanan publik. Pengukuran kinerja Pemerintah Daerah sebagai alat bagi manajemen organisasi untuk meningkatkan kualitas dalam rangka pengambilan keputusan dan akuntabilitas untuk menilai keberhasilan maupun kegagalan pelaksanaan kegiatan sesuai sasaran dan tujuan yang telah ditetapkan dalam rangkan mewujudkan visi dan misi organisasi Pemerintah Daerah (Halim, 2017). Pengukuran kinerja Pemerintah Daerah dilakukan melalui penilaian yang sistematik bukan hanya pada input tetapi juga pada output, benefit dan impact yang ditimbulkan.

Kinerja Pemerintah Daerah yang baik, apabila Pemerintah Daerah memiliki kewenangan dan kemampuan untuk menggali sumber-sumber keuangan, megelola dan menggunakan keuangan sendiri yang cukup untuk membiayai penyelenggaraan pemerintahannya dan tidak menggantungkan bantuan kepada Pemerintah Pusat sehingga peran Pemerintah Daerah menjadi lebih dominan. Faktor yang mempengaruhi kinerja Pemerintah Daerah, diantaranya adalah pengawasan. Pengawasan Pemerintah Daerah adalah usaha, tindakan dan kegiatan yang ditujukan untuk menjamin penyelenggaraan Pemerintah Daerah terlaksana secara efisien dan efektif sesuai dengan ketentuan peraturan perundang-undangan. Pengawasan ini bertujuan mencegah sedini mungkin terjadinya penyimpangan, pemborosan, penyelewengan, hambatan, kesalahan, dan kegagalan dalam mencapai tujuan dan pelaksanaan tugas-tugas organisasi.(Dewi dan Harimuri, 2017). Untuk dapat mewujudkan good corporate governance maka pengawasan dalam instansi pemerintah dilakukan oleh BPKP, kemudian informasi hasil dari pengawasan selanjutnya disampaikan kepada Presiden (Lintong, dkk., 2017).

Kinerja Pemerintah Daerah juga dipengaruhi oleh sistem akuntansi. Sistem akuntansi yang baik dapat menggambarkan bagaimana kinerja Pemerintah Daerah untuk menunjukan pencapaian yang dicapai. Agar kinerja dapat terlaksana maka diperlukan sistem akuntansi Pemerintah Daerah yang mengolah semua transaksi keuangan, asset, liability dan ekuitas pemerintah yang menghasilkan informasi akuntansi dan laporan keuangan yang tepat waktu dengan mutu yang dapat diandalkan oleh pihak intern dan ekstern Pemerintah Daerah dalam rangka pengambilan keputusan (Halim, 2017). Pemerintah Daerah memiliki kewenangan untuk mengelola sumber daya yang dimilikinya dan hal ini berbanding lurus dengan kewajiban yang diemban oleh Pemerintah Daerah, yakni mempunyai kewajiban melaporkan dan mempertanggungjawabkan pengelolaan sumber daya tersebut. Oleh karena itulah, sistem akuntansi menjadi tuntutan sekaligus kebutuhan bagi Pemerintah Daerah untuk meningkatkan kinerja Pemerintah Daerah.

Faktor lain yang mempengaruhi kinerja suatu Pemerintah Daerah adalah yaitu pengelolaan keuangan daerah. Dengan pengelolaan keuangan yang baik maka dapat meningkatkan kinerja Pemerintah Daerah. Keberhasilan otonomi daerah tidak lepas dari kinerja Pemerintah Daerah dalam mengelola keuangan daerahnya. Pengelolaan keuangan daerah merupakan keseluruhan kegiatan yang meliputi perencanaan, penganggaran, pelaksanaan, penatausahaan, pelaporan, pertanggungjawabn dan pengawasan keuangan daerah. Selain diatur dengan Peraturan Pemerintah, Keuangan 
Daerah juga diatur dengan Peraturan Menteri dan Undang-undang Anggaran Pendapatan Belanja Negara yang ditetapkan setiap tahun dan Anggaran Pendapatan dan Belanja Daerah masing-masing daerah yang disinkronkan dan dikelola secara sistematis. Pengelolaan Keuangan Daerah diwujudkan dalam Anggaran Pendapatan dan Belanja Daerah (APBD) yang merupakan salah satu perencanaan Pemerintah Daerah dalam mencapai tujuan penyelenggaran pemerintahan. Laporan pertanggungjawaban menjadi salah satu kewajiban Pemerintah Daerah dalam rangka pengelolaan keuangan daerah yang akuntabel dan transparan yang diwujudkan dalam bentuk laporan keuangan.

Penelitian ini dilakukan dengan harapan akan semakin memperkuat dari hasil penelitian sebelumnya. Penelitian yang dilakukan Novitasari dan Prabowo (2020) menunjukkan bahwa pengawasan internal berpengaruh positif dan signifikan terhadap kinerja SKPD, hal tersebut mampu membuktikan bahwa pengawasam internal yang baik apabila terdapat control yang bagus, dapat memberikan kepercayaan terhadap masyarakat dan pengawasan yang sesuai dengan indikator yang ada. Pengelolaan Keuangan Daerah berpengaruh positif dan signifikan terhadap kinerja SKPD hal tersebut mampu membuktikan bahwa Pengelolaan Keuangan Daerah yang baik apabila dapat meminimalisir pembengkakan pengeluaran yang tidak diinginkan, terbentuknya sistem penganggaran yang tidak rumit sehingga dapat diakses dan dan dapat menciptakan lingkungan kerja yang sehat.

Demikian halnya dengan penelitian Ulama (2018) yang menunjukkan bahwa secara parsial Pengelolaan Keuangan Daerah berpengaruh signifikan terhadap kinerja Pemerintah Daerah, secara parsial menunjukan bahwa sistem akuntansi keuangan daerah berpengaruh signifikan terhadap Kinerja Pemerintah Daerah dan secara simultan pengelolaan keuangan daerah dan sistem akuntansi keuangan daerah secara bersamasama berpengaruh signifikan terhadap variabel terikat yaitu kinerja Pemerintah Daerah. Selanjutnya Annisa (2017), hasil penelitiannya menunjukkan bahwa sistem akuntansi keuangan daerah secara parsial berpengaruh signifikan terhadap kinerja Pemerintah Daerah, pengelolaan keuangan daerah secara parsial berpengaruh signifikan terhadap kinerja Pemerintah Daerah dan good governance secara parsial berpengaruh signifikan terhadap kinerja Pemerintah Daerah.

\section{METODE PENELITIAN}

1. Jenis data yang akan digunakan dalam penyusunan penelitian ini adalah data kuantitatif. Sumber data yang akan digunakan dalam penyusunan penelitian ini adalah data primer melalui penyebaran kuesioner.

2. Populasi dalam penelitian ini adalah 153 orang pegawai dan untuk mengetahui jumlah sampel, maka pada penelitian ini didasarkan pada pendapat Slovin (Umar, 2013) sehingga sampel sebanyak 60 orang pegawai. Sebelum dilakukan pengujian hipotesis, perlu dilakukan pengujian asumsi klasik agar model regresi menjadi lebih representative. Untuk menjawab masalah penelitian, digunakan teknik analisis linear berganda (Multiple Regression Analysis) yang bertujuan untuk menguji pengaruh variabel independen (Pengawasan, Sistem Akuntansi dan Pengelolaan Keuangan Daerah) terhadap variabel dependen (Kinerja Pemerintah Daerah).

\section{HASIL DAN PEMBAHASAN}




\section{AkMen}

\section{Hasil}

\section{Uji Asumsi Klasik}

\section{Uji Normalitas}

Untuk menjamin data dari sampel penelitian telah berdistribusi normal, maka dilakukan pengujian normalitas data dengan menggunakan analisa grafik normal P-P Plot of Regression Standardized Residual terhadap masing-masing variabel yaitu pengawasan, sistem akuntansi dan pengelolaan keuangan daerah terhadap kinerja Pemerintah Daerah.

\section{Gambar 1.Uji Normalitas}

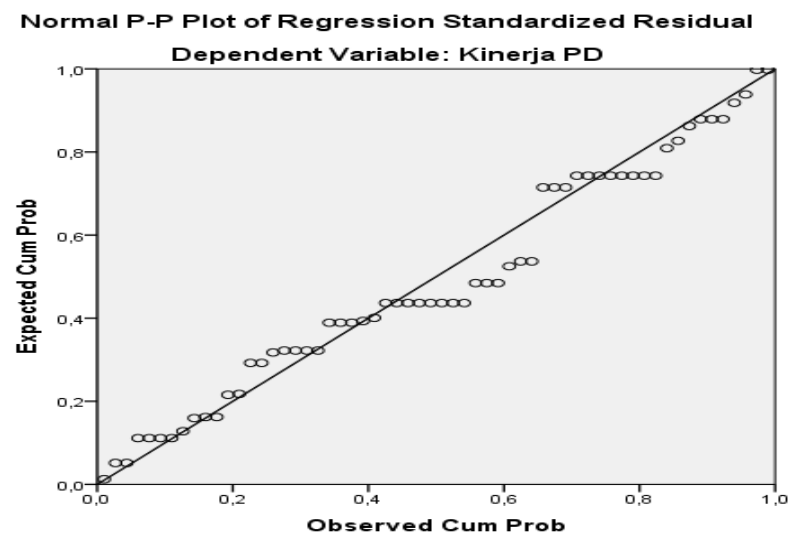

Hasil pengujian tersebut menunjukkan bahwa seluruh data telah berdistribusi secara normal pada seluruh variabel. Data menyebar di sekitar garis diagonal dan mengikuti arah garis diagonalnya, maka model regresi memenuhi asumsi normalitas.

\section{Uji Mltikolinearitas}

Pendeteksian multikolinearitas juga dapat dilakukan melalu nilai VIF. Jika nilai VIF lebih besar dari 10 (VIF > 10), maka diperkirakan terjadi multikolinear, namun jika nilai VIF lebih kecil 10 (VIF < 10), maka diperkirakan tidak terjadi multikolinear.

\section{Tabel 1. Uji Multikolinearitas}

\begin{tabular}{|c|c|c|c|c|c|c|c|c|}
\hline \multicolumn{9}{|c|}{ Coefficients $^{\mathrm{a}}$} \\
\hline & & \multicolumn{2}{|c|}{$\begin{array}{c}\text { Unstandardized } \\
\text { Coefficients }\end{array}$} & \multirow{2}{*}{$\begin{array}{c}\begin{array}{c}\text { Standardized } \\
\text { Coefficients }\end{array} \\
\text { Beta }\end{array}$} & \multirow[b]{2}{*}{$\mathrm{T}$} & \multirow[b]{2}{*}{ Sig. } & \multicolumn{2}{|c|}{$\begin{array}{l}\text { Collinearity } \\
\text { Statistics }\end{array}$} \\
\hline \multicolumn{2}{|c|}{ Model } & $\mathrm{B}$ & Std. Error & & & & Tolerance & VIF \\
\hline \multirow[t]{4}{*}{1} & (Constant) &, 555 &, 514 & & 1,080 & ,285 & & \\
\hline & Pengawasan & ,420 & 108 & ,409 & 3,886 & ,000 & ,769 & 1,301 \\
\hline & Sistem Akuntansi & ,216 & ,072 & ,321 & 3,002 & ,004 &, 747 & 1,338 \\
\hline & Pengelolaan KD & ,211 &, 100 & ,253 & 2,117 & 039 & ,598 & 1,672 \\
\hline
\end{tabular}

a. Dependent Variable: Kinerja PD

Berdasarkan tabel Output Coefficients pada bagian Collinearity diketahui nilai VIF (variance inflation factor) untuk variabel Pengawasan, Sistem Akuntansi dan Pengelolaan Keuangan Daerah tidak melebihi angka 10. Maka dapat disimpulkan bahwa tidak terjadi gelaja multikolinieritas dalam model regresi. 


\section{AkMen}

Uji Heterokedastisitas

Asumsi homoskedastisitas atau penyebaran (scedasticity) sama (homo), yaitu varians yang sama. Kebalikan dari homoskedastisitas adalah heteroskedastisitas yang tidak lain merupakan pelanggaran asumsi klasik.

\section{Gambar 2.Uji Heterokedastisitas}

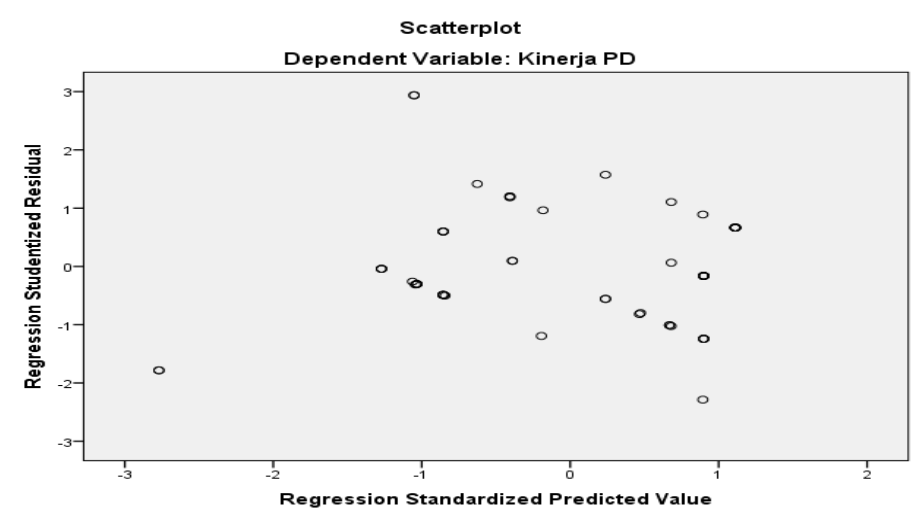

Berdasarkan Output Scatterplots diketahui bahwa titik-titik data menyebar diatas dan dibawah atau sekitar angka 0 (nol). Penyebaran titik-titik data tidak membentuk pola sehingga dapat disimpulkan bahwa tidak terjadi masalah heterokedastisitas, sehingga model regresi yang baik dan ideal dapat terpenuhi.

\section{Uji Regresi Berganda}

Analisis ini digunakan untuk mengetahui arah dan besarnya pengaruh pengawasan, sistem akuntansi dan pengelolaan keuangan daerah terhadap kinerja Pemerintah Daerah. Hasil pengolahan data berupa persamaan regresi yang tertera pada tabel 2 berikut ini:

\section{Tabel 2. Koefisien Regresi}

Coefficients $^{\mathrm{a}}$

\begin{tabular}{|c|c|c|c|c|c|c|}
\hline \multirow{2}{*}{\multicolumn{2}{|c|}{ Model }} & \multicolumn{2}{|c|}{$\begin{array}{c}\text { Unstandardized } \\
\text { Coefficients }\end{array}$} & \multirow{2}{*}{$\begin{array}{c}\text { Standardized } \\
\text { Coefficients }\end{array}$} & \multirow[b]{2}{*}{$\mathrm{t}$} & \multirow[b]{2}{*}{ Sig. } \\
\hline & & $\mathrm{B}$ & Std. Error & & & \\
\hline \multirow[t]{4}{*}{1} & (Constant) &, 555 &, 514 & & 1,080 & 285 \\
\hline & Pengawasan & ,420 & ,108 & ,409 & 3,886 & ,000 \\
\hline & Sistem Akuntansi & ,216 &, 072 & ,321 & 3,002 & ,004 \\
\hline & Pengelolaan KD & ,211 &, 100 & ,253 & 2,117 & ,039 \\
\hline
\end{tabular}

a. Dependent Variable: Kinerja PD

Berdasarkan tabel 2 dapat diketahui hasil analisis regresi berganda yang diformulasikan dalam persamaan regresi sebagai berikut:

$$
Y=0,555+0,420 X_{1}+0,216 X_{2}+0,211 X_{3}
$$

1. Koefisien $b_{0}=0,555$ artinya apabila variabel pengawasan $\left(X_{1}\right)$, sistem akuntansi $\left(\mathrm{X}_{2}\right)$ dan pengelolaan keuangan daerah $\left(\mathrm{X}_{3}\right)$ tidak mengalami perubahan 
(konstan), maka kinerja Pemerintah Daerah (Y) tidak akan berubah.

2. Koefisien $b_{1}=0,420$ artinya setiap peningkatan variabel pengawasan $\left(X_{1}\right)$, maka diharapkan dapat meningkatkan kinerja Pemerintah Daerah (Y) sebesar $42 \%$.

3. Koefisien $b_{2}=0,216$ artinya setiap peningkatan variabel sistem akuntansi $\left(X_{2}\right)$, maka diharapkan dapat meningkatkan kinerja Pemerintah Daerah (Y) sebesar $21,6 \%$.

4. Koefisien $b_{3}=0,211$ artinya setiap peningkatan variabel pengelolaan keuangan daerah $\left(\mathrm{X}_{3}\right)$, maka diharapkan dapat meningkatkan kinerja Pemerintah Daerah (Y) sebesar 21,1\%.

\section{Uji Hipotesis}

\section{Uji Simultan (Uji F)}

Pengujian secara simultan (uji F) dilakukan untuk mengetahui apakah semua variabel independen $\mathrm{X}_{\mathrm{i}}$ (pengawasan, sistem akuntansi dan pengelolaan keuangan daerah) secara simultan memiliki pengaruh yang signifikan terhadap variabel dependen kinerja Pemerintah Daerah (Y).

\section{Tabel 3. Hasil Uji F}

\begin{tabular}{|ll|r|r|r|r|r|}
\hline Model & & Sum of Squares & df & Mean Square & F & Sig. \\
\hline 1 & Regression & 6,295 & 3 & 2,098 & 20,404 &, $000^{\mathbf{b}}$ \\
& Residual & 5,759 & 56 &, 103 & & \\
& Total & 12,053 & 59 & & & \\
\hline
\end{tabular}

a. Dependent Variable: Kinerja PD

b. Predictors: (Constant), Pengelolaan KD, Pengawasan, Sistem Akuntansi

Berdasarkan table output SPSS, diketahui Nilai $\mathrm{F}_{\text {hitung }}$ sebesar 20,404 > nilai $\mathrm{F}_{\text {tabel }}$ 2,76 dengan level signifikansi sebesar $0,000<0,05$, maka sesuai dengan dasar pengambilan keputusan dalam uji F dapat disimpulkan bahwa Pengawasan (X1), Sistem Akuntansi (X2) dan Pengelolaan Keuangan Daerah (X3) secara simultan berpengaruh positif dan signifikan terhadap kinerja Pemerintah Daerah (Y). Untuk melihat keeratan hubungan antar variable X (Pengawasan, Sistem Akuntansi dan Pengelolaan Keuangan Daerah) dengan Y (Kinerja Pemerintah Daerah) serta seberapa besar kontribusi pengaruh ketiga variabel tersebut terhadap Kinerja Pemerintah Daerah dapat diketahui dalam tabel hasil uji determinasi dibawah ini:

\section{Tabel 4. Hasil Uji Determinasi}

\begin{tabular}{|l|r|r|r|c|}
\hline Model & $\mathrm{R}$ & M Square & \multicolumn{1}{|c|}{$\begin{array}{c}\text { Adjusted R } \\
\text { Square }\end{array}$} & $\begin{array}{c}\text { Std. Error of the } \\
\text { Estimate }\end{array}$ \\
\hline 1 &, $723^{\mathrm{a}}$ &, 522 &, 497 &, 32067 \\
\hline
\end{tabular}

a. Predictors: (Constant), Pengelolaan KD, Pengawasan, Sistem Akuntansi

Tabel diatas menunjukkan bahwa nilai koefisien korelasi $(\mathrm{R})$ sebesar 0,723 yang berarti bahwa adanya hubungan yang kuat antara variabel $\mathrm{X}$ (Pengawasan, Sistem Akuntansi dan Pengelolaan Keuangan Daerah) dengan variabel Y (Kinerja Pemerintah Daerah). Nilai positif menunjukkan hubungan searah dimana variabel pengawasan, sistem akuntansi dan pengelolaan keuangan daerah jika ditingkatkan, maka kinerja Pemerintah Daerah pun akan meningkat.. Nilai $\mathrm{R}^{2}=0,522$ memperlihatkan besarnya 
kontribusi ketiga variabel X (Pengawasan, Sistem Akuntansi dan Pengelolaan Keuangan Daerah) terhadap variabel Y (Kinerja Pemerintah Daerah) sebesar 52,2\%. Masih terdapat variable lainnya yang mampu meningkatkan variable kinerja Pemerintah Daerah yaitu sebesar 47,8\%.

\section{Uji Parsial (Uji t)}

Bertujuan untuk mengetahui apakah variabel Pengawasan (X1), Sistem Akuntansi (X2) dan Pengelolaan Keuangan Daerah (X3) secara parsial berpengaruh terhadap variabel Kinerja Pemerintah Daerah (Y). Adapun hipotesis yang diajukan dalam penelitian ini adalah:

1. H1 : Terdapat pengaruh Pengawasan (X1) terhadap Kinerja Pemerintah Daerah (Y)

2. H2 : Terdapat pengaruh Sistem Akuntansi (X2) terhadap Kinerja Pemerintah Daerah (Y)

3. H3 : Terdapat pengaruh Pengelolaan Keuangan Daerah (X3) terhadap Kinerja Pemerintah Daerah (Y)

Berdasarkan table Coefficients, diketahui Nilai $t_{\text {hitung variabel Pengawasan sebesar }}$ $3,886>t_{\text {tabel }}$ sebesar 1,670 dengan tingkat signifikansi sebesar $0,000<$ probabilitas 0,05 maka dapat disimpulkan bahwa hipotesis pertama diterima yang berarti variabel Pengawasan (X1) berpengaruh positif dan signifikan terhadap Kinerja Pemerintah

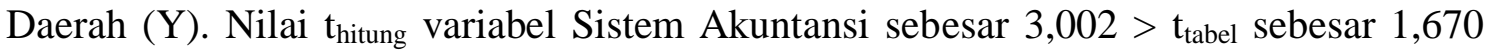
dengan tingkat sifnifikansi sebesar $0,004<$ probabilitas 0,05 maka dapat disimpulkan bahwa hipotesis kedua diterima yang berarti variabel Sistem Akuntansi (X2) berpengaruh positif dan signifikan terhadap Kinerja Pemerintah Daerah (Y). Variabel Pengelolaan Keuangan Daerah (X3) juga memiliki pengaruh positif dan signifikan terhadap Kinerja Pemerintah Daerah (Y) yang diketahui melalui $t_{\text {hitung }}$ sebesar 2,117 > $\mathrm{t}_{\text {tabel }}$ 1,670 dengan tingkat signifikansi variabel Pengelolaan Keuangan Daerah (X3) sebesar $0,039<$ probabilitas 0,05 .

\section{Pembahasan}

Hasil pengolahan data mengemukakan bahwa variabel Pengawasan, Sistem Akuntansi dan Pengelolaan Keuangan Daerah memiliki pengaruh yang nyata terhadap peningkatan Kinerja Pemerintah Daerah. Untuk itu, penjelsan pengaruh antar variabel akan diuraikan sebagai berikut:

\section{Pengaruh Pengawasan Terhadap Kinerja Pemerintah Daerah}

Pengawasan berpengaruh positif dan signifikan terhadap kinerja Pemerintah Daerah, hal ini berarti bahwa pengawasan memiliki hubungan yang searah dengan kinerja Pemerintah Daerah. Dengan hasil tersebut mengindikasikan bahwa dengan diterapkannya pengawasan yang baik dapat meningkatkan kinerja Pemerintah Daerah. Hasil penelitian ini membuktikan bahwa semakin tinggi pengawasan yang diterapkan maka semakin tinggi kinerja Pemerintah Daerah. Hasil penelitian ini menunjukkan bahwa pengawasan pemerintah merupakan syarat terciptanya kinerja Pemerintah Daerah yang berdisiplin dan bertanggungjawab. Hal ini sesuai dengan teori yang dikemukakan oleh Bastian (2016), bahwa pengawasan internal yang meliputi struktur organisasi, metode, dan ukuran-ukuran yang dikoordinasikan untuk menjaga kekayaan 
organisasi, mengecek ketelitian dan keandalan data akuntansi, mendorong efisiensi, dan dipatuhinya kebijakan pimpinan.

Pengawasan internal dijadikan sebagai pengwasan awal terhadap pencapaian kinerja Pemerintah Daerah. Dengan demikian kinerja Pemerintah Daerah akan lebih terarah dalam pencapaian sasarannya. Selain itu penyimpangan dan penyelewengan juga akan terminimalisir kerena satuan kerja menggunakan prosedur yang merupakan bagian dari pengawasan sebagai salah satu dasar pelaksanaan kegiatan. Hal ini sesuai dengan pendapat Halim (2017), bahwa pengawasan dapat membantu organisasi dalam mencapai prestasi dan target yang menguntungkan, dan mencegah kehilangan sumber daya. Dapat membantu menghasilkan laporan keuangan yang dapat dipercaya. Dan juga dapat memastikan suatu organisasi mematuhi perundang-undangan dan peraturan, terhindar dari reputasi yang buruk dan segala konsekuensinya. Selanjutnya dapat pula memmbantu mengarahkan suatu organisasi untuk mencapai tujuannya, dan terhindar dari hal-hal yang merugikan.

\section{Pengaruh Sistem Akuntansi Terhadap Kinerja Pemerintah Daerah}

Sistem akuntansi berpengaruh positif dan signifikan terhadap kinerja Pemerintah Daerah, hal ini berarti bahwa sistem akuntansi memiliki hubungan yang searah dengan kinerja Pemerintah Daerah. Dengan hasil tersebut mengindikasikan bahwa dengan sistem akuntansi yang baik dapat meningkatkan kinerja Pemerintah Daerah. Hasil penelitian ini membuktikan bahwa dengan semakin baiknya sistem akuntansi, maka kinerja Pemerintah Daerah akan semakin baik. Hal ini memberitahukan bahwa sistem akuntansi bisa menyebabkan dukungan yang baik terhadap kinerja Pemerintah Daerah. Hasil penelitian ini menerangkan bahwa sistem akuntansi Pemerintah Daerah merupakan sistem terpadu yang menggabungkan mekanisme manual yang menggunakan proses elektronik pada pengambilan data pembukuan dan pelaporan seluruh transaksi keuangan yang terkait dengan aset, kewajiban dan ekuitas semua entitas Pemerintah Daerah.

Untuk bisa membuat laporan keuangan yang relevan, handal dan bisa dipercaya, Pemerintah wajib mempunyai system akuntansi yang handal karena dengan system akuntansi yang lemah akan mengakibatkan laporan keuangan menyediakan informasi yang kurang handa dan nirrelevan yang akhirnya bisa menyebabkan lahirnya keputusan yang tidak baik. Sistem akuntansi bisa memberikan informasi atas aturan yang sudah terealisasi dengan cara yang sudah ditetapkan, dengan demikian bisa dikatakan sistem akuntansi keuangan daerah bisa mengakibatkan dukungan terhadap kinerja Pemerintah Daerah. Hasil penelitian ini sesuai dengan penelitian Ireeuw (2019) yang menyatakan bahwa sistem akuntansi berpengaruh secara signifikan terhadap kinerja pemerintah daerah, hal ini berarti kinerja pemerintah daerah akan tercapai dengan dilaksanakannya sistem akuntansi keuangan daerah, dan sistem akuntansi keuangan daerah dapat menimbulkan dukungan yang kuat terhadap kinerjapemerintah yang dicapai.

\section{Pengaruh Pengelolaan Keuangan Daerah Terhadap Kinerja Pemerintah Daerah}

Pengelolaan keuangan daerah berpengaruh positif dan signifikan terhadap kinerja Pemerintah Daerah, hal ini berarti bahwa pengelolaan keuangan daerah memiliki hubungan yang searah dengan kinerja Pemerintah Daerah. Dengan hasil tersebut mengindikasikan bahwa dengan pengelolaan keuangan daerah yang baik dapat 
meningkatkan kinerja Pemerintah Daerah. Hasil penelitian ini membuktikan bahwa semakin baik pengelolaan keuangan daerah yang dilaksanakan maka semakin baik kinerja Pemerintah Daerah. Hasil penelitian ini menerangkan bahwa pengelolaan keuangan daerah adalah dasar terciptanya kinerja Pemerintah Daerah yang baik.

Selain itu, output penelitian ini menegaskan pentingnya pengelolaan keuangan daerah pada peningkatan kinerja Pemerintah Daerah, dengan adanya kinerja Pemerintah Daerah yang baik akan berdampak positif terhadap kesejahteraan masyarakat dan para pengguna laporan. Hal ini sejalan dengan teori yang dikemukakan oleh Chabib (2016), bahwa akuntansi pemerintahan menaruh fakta keuangan berdasarkan entitas-entitas nirlaba. Hasil penelitian ini juga menerangkan bahwa implementasi pengelolaan keuangan daerah berpengaruh terhadap kinerja Pemerintah Daerah, implementasi sistem pengelolaan keuangan daerah menekankan dalam hubungan antara dana yang dianggarkan menggunakan output-output yang ingin dicapai.

\section{KESIMPULAN}

Berdasarkan hasil penelitian dan pembahasan yang telah dikemukakan, maka kesimpulan dalam penelitian ini adalah:

1. Pengawasan memberikan pengaruh yang positif dan signifikan terhadap kinerja Pemerintah Daerah, hal ini menerangkan bahwa semakin baik pengawasan yang dilakukan, maka semakin baik kinerja Pemerintah Daerah.

2. Sistem akuntansi memberikan pengaruh yang positif dan signifikan terhadap kinerja Pemerintah Daerah, hal ini menerangkan bahwa semakin baik sistem akuntansi yang diterapkan, maka semakin baik kinerja Pemerintah Daerah.

3. Pengelolaan keuangan daerah memberikan pengaruh yang positif dan signifikan terhadap kinerja Pemerintah Daerah, hal ini menerangkan bahwa semakin baik pengelolaan keuangan daerah yang dilakukan, maka semakin baik kinerja Pemerintah Daerah.

\section{SARAN}

Adapun saran-saran yang dapat diajukan oleh peneliti sebagai berikut:

1. Pengawasan pada Pemerintah Daerah sebaiknya menekankan pada tujuan yang hendak dicapai dan bukan pada unsur-unsur yang dibentuk sistem tersebut sehingga pengawasan Pemerintah Daerah bisa berjalan secara optimal.

2. Sistem akuntansi pada Pemerintah Daerah ditekankan pada proses pencatatan dan dilakukan dengan lebih teliti supaya menghindari transaksi yang tidak tercatat dan harus didokumentasikan, serta dilakukan pengawasan terhadap transaksi-transaksi yang terjadi dan peningkatan sistem atau aplikasi yang memadai agar proses pencatatan dan pelaporan lebih efektif.

3. Pengelolaan keuangan daerah pada Pemerintah Daerah dalam pelaksanaannya harus dapat dipertanggungjawabkan kepada Pemerintah Pusat, agar kinerja Pemerintah Daerah berjalan dengan baik dan optimal dalam rangka mengantisipasi terjadinya praktek KKN pada lingkungan Pemerintah Daerah.

\section{DAFTAR PUSTAKA}

Annisa, Vivid. 2017. The Influence of Regional Financial Accounting Systems, Regional Financial Management, and Good Government Governance on Local Government Performance. JOM Fekon, Vol.4 No. 1, 1-13. 
Bastian, Indra.2016. Public Sector Accounting an Introduction. Third Edition.Publisher:Erlangga. Jakarta.

Chabib Soleh. 2016. Assessing Local Government Performance. Publisher:Fokus Media. Bandung.

Dewi SPA and Harimurti Fadjar. 2017. The Effect of Internal Control, Regional Financial Accounting Systems and Regional Financial Management on Regional Financial Performance of the Karanganyar Regency Government. EKSPLORASI.Volume XXIX No. 2.Universitas Slamet Riyadi Surakarta.

Halim, Abdul. 2017. Akuntansi Daerah Sektor Publik. Publisher:Salemba Empat. Jakarta.

Ireeuw. M. Stevani Veronica. 2019. The Effect of Regional Financial Management and the Regional Financial Accounting System on the Performance of Local Government in the Regional Apparatus Organization of Jayapura City. Jurnal Akuntansi dan Keuangan Daerah.Vol 14 No 1. Universitas Cendrawasih.

Lintong Diana Nova, Saerang David Paul dan Ilat Ventje. 2017. The Influence of the Implementation of the Regional Financial Management Accounting System and Internal Control on the Performance of the Municipal Government of Kotamabagu. Jurnal Accountability.Volume 06 Nomor 01.Universitas Sam Ratulangi.

Novitasari Dea Rahma dan Prabowo Tri Jatmiko. 2020. The Effect of Regional Financial Management and Internal Control on Government Performance in Semarang City Government Work Unit. Diponegoro Journal Of Accounting. Vol 9 No 2. Universitas Diponegoro.

Sugiyono. 2016. Qualitative and Quantitative Research Methods R\&D. Publisher:Alfabeta. Bandung.

Ulama Fatra. 2018. The Effect of Regional Financial Management and the Regional Financial Accounting System on the Performance of Regional Government of Gorontalo City. Scientific Articles. Universitas Negeri Gorontalo.

Umar, Husein. 2013. Research Methods for Thesis and Business Thesis. Second Edition.Publisher: PT Raja Grafindo Persada. Jakarta. 